\title{
A Role for Dogs in Advancing Cancer Immunotherapy Research
}

\author{
Steven Dow* \\ Flint Animal Cancer Center, Department of Clinical Sciences, College of Veterinary Medicine and Biomedical Sciences, \\ Colorado State University, Fort Collins, CO, United States
}

While rodent cancer models are essential for early proof-of-concept and mechanistic studies for immune therapies, these models have limitations with regards to predicting the ultimate effectiveness of new immunotherapies in humans. As a unique spontaneous, large animal model of cancer, the value of conducting studies in pet dogs with cancer has been increasingly recognized by the research community. This review will therefore summarize key aspects of the dog cancer immunotherapy model and the role that these studies may play in the overall immunotherapy drug research effort. We will focus on cancer types and settings in which the dog model is most likely to impact clinical immuno-oncology research and drug development. Immunological reagent availability is

OPEN ACCESS

Edited by:

Mark W. Dewhirst,

Duke University, United States

Reviewed by:

Silvia C. Formenti,

Weill Cornell Medicine, Cornell

University, United States

Xiaobo Zhang

Zhejiang University, China

Elizabeth Ann Repasky,

Roswell Park Comprehensive Cancer

Center, University at Buffalo,

United States

*Correspondence:

Steven Dow

sdow@colostate.edu

Specialty section:

This article was submitted to

Comparative Immunology,

a section of the journal

Frontiers in Immunology

Received: 02 August 2019 Accepted: 29 November 2019

Published: 17 January 2020

Citation:

Dow S (2020) A Role for Dogs in Advancing Cancer Immunotherapy

Research. Front. Immunol. 10:2935.

doi: 10.3389/fimmu.2019.02935 discussed, along with some unique opportunities and challenges associated with the dog immunotherapy model. Overall it is hoped that this review will increase awareness of the dog cancer immunotherapy model and stimulate additional collaborative studies to benefit both man and man's best friend.

Keywords: canine, immune, cell, cytokine, oncology

\section{INTRODUCTION}

Cancer immunotherapy continues to make remarkable strides in just the few years since the first checkpoint molecule targeted therapeutic antibodies were evaluated in trials and approved by the FDA. Indeed, there is the sense by the author and colleagues in the veterinary immuneoncology community (Personal Communication, 2019) that the field of human immune-oncology is advancing so rapidly that new immunotherapy combinations are being evaluated before there is time to determine whether the combinations are truly effective, as judged by evidence of synergistic or additive antitumor activity in realistic animal models $(1,2)$. Thus, there is a need for additional animal models with which to evaluate new cancer immunotherapies, particularly novel immunotherapy combinations, including immunotherapy combined with targeted therapies, chemotherapy, and radiation therapy. Current rodent cancer models have certain limitations with regards to predicting the ultimate effectiveness of new immunotherapies in humans (3-5).

Increasingly the NIH and pharmaceutical and biotechnology companies are looking to alternative animal models with which to screen immunotherapeutic drugs. The dog spontaneous cancer model has received considerable attention recently $(4,6-13)$. Several factors drive interest in the dog model. For example, dogs spontaneously develop cancer that resembles human malignancies in many important respects, including phenotype, biological behavioral, histology, mutational signatures and signaling pathways, and immune responses. Indeed, the value of the dog cancer model was recently recognized by the National Institute of Medicine (9).

Therefore, this review will summarize key aspects of the dog cancer model that make it particularly well-suited to evaluating cancer immunotherapies and drug combinations. This will 
not however be a comprehensive review of all dog cancer immunotherapy studies, which have been reviewed elsewhere and are beyond the scope of this work $(3,14-20)$. We will instead focus on areas of investigation in which the dog model currently may be most likely to impact clinical immuno-oncology research and new drug development. Reagent availability is also discussed, along with some challenges faced by the dog immunotherapy model along with strategies to overcome these challenges. The intent of this review is to increase awareness of the dog cancer model and stimulate additional studies, which in many cases may benefit both man and man's best friend.

\section{THE CANINE CANCER MODEL AND RELEVANCE TO IMMUNOLOGICAL STUDIES}

The uniquely valuable aspects of the canine cancer model have been well-covered in recent reviews $(6,7,13)$. With regards to immunological studies in general, there are several key differences between dogs and rodents. For one, dogs are considered an immunologically outbred species, though there are genetic bottlenecks (i.e., limited genotypic or phenotypic diversity within breeds due to extensive inbreeding) for certain breeds of dogs (13). In fact, the availability of dog breeds can in some cases make it possible to map genetic loci to certain immunological traits, as in the example of susceptibility to lymphoma in dogs (21). For example, it was reported that usage of certain $\mathrm{VH}$ genes has been associated with improved survival times in canine B cell lymphoma, a dog model for human nonHodgkin lymphoma (22). Other cancer traits have also been mapped to specific genetic loci in dogs by taking advantage of dog breed genetics (23-26).

Another relevant aspect of the dog model is that the immune system of dogs in cancer immunotherapy studies is typically already very immunologically experienced, with animals having experienced exposure to multiple immunizations during their early years, and to multiple different viral and bacterial infections prior to development of cancer. These immunological events all shape the immune repertoire of dogs and consequently render the dog much more immunologically experienced than rodents raised in sterile cages and fed sterilized water and chow. Dogs also share the same environment of their human companions, and are therefore exposed to many of the same allergens, food antigens, and environmental chemicals $(6,8)$. Thus, it is not surprising that dogs may react to an immunotherapeutic drug in a different manner than rodents, and behave in many ways more analogously to humans.

Dogs also develop tumors spontaneously, which means that the immune system has typically had weeks to months to recognize the tumor and mount immune responses prior to the appearance of a tumor large enough to diagnose. This longterm exposure to tumor antigens and secreted factors thus educates and conditions the canine immune system in a way that cannot be recapitulated in rodent implanted or induced tumor models $(3,5,27)$. Moreover, the canine immune system is much more broadly "educated" which will shape the development of antitumor immunity.

From the standpoint of dosing immunotherapy drugs (other than vaccines), dogs with their similar body sizes and metabolic pathways also fill a gap not currently addressed by rodent studies. Drugs dosed based on weight or body surface area in dogs are much more likely to predict drug activity and toxicity than drugs dosed in mice frequently treated at much higher drug concentrations than can be tolerated by human patients (8). This feature of studies in dogs would be particularly relevant for dosing small molecule drugs and biologics such as monoclonal antibodies, where volume of distribution is critical for determining activity and toxicity $(6,8,10,13)$. The larger size of dogs and their tumors also makes repeated access to blood and tumor tissue biopsies a possibility, which is often important in immunological studies to assess the progression of immune responses, as for example changes in immune infiltrates in tumor tissues.

\section{COMPARISON OF DOG AND HUMAN IMMUNE CELLS AND IMMUNE RESPONSES}

The canine immune system and immune responses in general are very similar to those of humans, with a few notable differences. In broad terms, numbers and proportions of $\mathrm{T}$ cells (CD4 and CD8) and B cells in blood of adult dogs closely resemble those of humans (Schalm's Veterinary Hematology, 7th edition and Clinical Immunology of the Dog and Cat, 2nd edition). Moreover, the ratio of CD4 to CD8 T cells $(\sim 2: 1)$ in blood and lymph nodes is similar in dogs and humans. Numbers and percentages of neutrophils and monocytes in blood of both species are also very similar. However, recent reagent development for canine $\mathrm{NK}$ cells may improve our ability to quantitate dog NK cell responses $(28,29)$. Dogs also have circulating gamma-delta $\mathrm{T}$ cells, though little is known regarding how their numbers may change in disease states (30). Regulatory T cells (CD4+FoxP3+) in dogs have also been defined, and their numbers shown to be significantly increased in dogs with cancer, in both blood and tumor-draining lymph nodes (31-33).

Circulating concentrations of immunoglobulins in adult dogs are approximately the same as those of adult humans, though much less is known about normal immunoglobulin concentrations in young dogs and when final adult IgG concentrations are attained (Schalm's Veterinary Hematology, 7th edition and Clinical Immunology of the Dog and Cat, 2nd edition). Canine IgG molecules can be classified into four functional subclasses (A-D), similar to the human IgG subclasses, with two subclasses capable of binding Fc receptors and two subclasses being Fc functionally negative (34).

$\mathrm{T}$ cells in dogs express many of the same co-stimulatory or co-inhibitory molecules as present in humans, including CD28, PD-1, OX40, TIGIT, TIM-3, and Lag3. Like human T cells, canine T cells constitutively express low levels of MHCII, which can be upregulated following $\mathrm{T}$ cell activation. In addition, 
canine effector $\mathrm{T}$ cells upregulate production of granzyme $\mathrm{B}$, in addition to CD25 and MHCII (35). Antigen presenting cell (B cells, DC, and monocyte and macrophages) in dogs also share many co-stimulatory or inhibitory molecules with human APC, including MHCII, CD40, CD80, CD86, PD-L1 expression (36-40). In addition, responses to activation, as for example with TLR ligands, is also similar, with upregulated expression of co-stimulatory molecules, and production of pro-inflammatory cytokines such TNF-a, IL-1b, and IL-6, and anti-inflammatory cytokines including IL-10 and TGF-b. In addition, canine monocytes express the chemokine receptor CCR2 and migrate in response to an MCP-1 gradient (41).

An unusual feature of dog neutrophils, which differs from neutrophils in humans, is their expression of CD4 (Schalm's Veterinary Hematology, 7th edition and Clinical Immunology of the Dog and Cat, 2nd edition). The function of CD4 molecule expression by canine neutrophils is unclear, and CD4 is not expressed by other myeloid lineage cells such as monocytes in dogs. Dogs also appear to have a greater abundance of mast cells than humans, especially in mucosal sites such as the skin and airways, and mast cell tumors are much more common in dogs than in humans. Dogs also develop malignancies of cells of the DC and macrophage lineage (e.g., malignant histiosarcoma) at a much higher rate than in humans (e.g., Langerhans histiocytosis) (42-44).

\section{SELECTED CANINE CANCER IMMUNOTHERAPY STUDIES WITH HIGH RELEVANCE TO HUMAN IMMUNO-ONCOLOGY}

Dogs will never replace rodent cancer models for cancer immunotherapy drug research and development, since early drug screening and mechanism of action studies can realistically only be done in rodent models. However, there are several tumor models where the dog may offer clear advantages, particularly for assessment of new immunotherapies and their potential efficacy against metastatic disease $(3,9,45)$. For example, the dog model may be uniquely valuable to address the following issues with respect to cancer immunotherapy: Can new cancer vaccines control advanced metastatic disease?; Can adoptive CAR $\mathrm{T}$ cell or NK cell therapy be both safe and active against solid tumors, and what is the safety profile?; How well do tumor microenvironment modifying agents work when combined with existing immunotherapies such as targeted drugs or checkpoint molecule antibodies?; Can checkpoint targeted therapeutics be effectively combined with other cancer treatment modalities (e.g., radiation therapy, cytotoxic chemotherapy) to control or prevent tumor metastases? These examples are discussed in greater detail below. A summary of key recent dog immunotherapy studies is provided in Table 1.

TABLE 1 | Summary of relevant canine cancer immunotherapy trials and results.

\begin{tabular}{|c|c|c|c|c|c|c|c|}
\hline Trial & Delivery & Tumor type & $\begin{array}{l}\text { Number } \\
\text { enrolled }\end{array}$ & $\begin{array}{l}\text { Study primary } \\
\text { endpoints }\end{array}$ & $\begin{array}{l}\text { Secondary } \\
\text { endpoints }\end{array}$ & Outcomes & References \\
\hline $\begin{array}{l}\text { Her2 neu } \\
\text { vaccine }\end{array}$ & $\begin{array}{l}\text { Listeria vectored } \\
\text { (IV) }\end{array}$ & Osteosarcoma & 18 & Time to metastasis & $\mathrm{T}$ cell responses & $\begin{array}{l}\text { Increase OST vs. } \\
\text { historical control }\end{array}$ & $(46)$ \\
\hline TERT vaccine & AAV vectored (IM) & $\begin{array}{l}\text { B cell } \\
\text { lymphoma }\end{array}$ & 14 & $\begin{array}{l}\text { Time to progression, } \\
\text { OST }\end{array}$ & TERT antibodies & $\begin{array}{l}\text { Increase OST vs. } \\
\text { historical control }\end{array}$ & $(47)$ \\
\hline $\begin{array}{l}\text { Vaccine plus } \\
\text { surgery }\end{array}$ & $\begin{array}{l}\text { Autologous tumor } \\
\text { lysate (SC) }\end{array}$ & Meningioma & 11 & Tumor progression & Antibody response & $\begin{array}{l}\text { No tumor progression } \\
\text { over } 6 \text { months }\end{array}$ & $(48)$ \\
\hline CD20 CAR T & $\begin{array}{l}\text { Transduced } \\
\text { autologous T cells }\end{array}$ & $\begin{array}{l}\text { B cell } \\
\text { Iymphoma }\end{array}$ & 1 & Safety & Tumor regression & $\begin{array}{l}\text { Safely tolerated, partial } \\
\text { tumor response }\end{array}$ & $(49)$ \\
\hline NK cell ACT & $\begin{array}{l}\text { Intratumoral } \\
\text { administration }\end{array}$ & Osteosarcoma & 10 & $\begin{array}{l}\text { Safety, tumor } \\
\text { regression }\end{array}$ & Tumor infiltrates & $\begin{array}{l}\text { Improved DFI, NK } \\
\text { localization }\end{array}$ & $(50)$ \\
\hline $\begin{array}{l}\text { Liposomal } \\
\text { clodronate }\end{array}$ & IV, repeat infusions & $\begin{array}{l}\text { Soft tissue } \\
\text { sarcoma }\end{array}$ & 13 & $\begin{array}{l}\text { Safety, macrophage } \\
\text { depletion }\end{array}$ & Tumor regression & $\begin{array}{l}\text { Macrophage depletion, } \\
\text { no tumor responses }\end{array}$ & $(51)$ \\
\hline CCR4 blockade & $\begin{array}{l}\text { Antagonist } \\
\text { antibody (IV) }\end{array}$ & $\begin{array}{l}\text { Bladder } \\
\text { cancer }\end{array}$ & 26 & Treg infiltrates & Survival, toxicity & $\begin{array}{l}\text { Improved OST, Treg } \\
\text { depletion }\end{array}$ & $(52)$ \\
\hline $\begin{array}{l}\text { IDO inhibitor } \\
\text { wth XRT }\end{array}$ & Oral & $\begin{array}{l}\text { Melanoma, } \\
\text { soft tissue } \\
\text { sarcom }\end{array}$ & 5 & Safety, tumor response & Reduction in Tregs & $\begin{array}{l}\text { Partial tumor response, } \\
\text { immune response }\end{array}$ & (53) \\
\hline $\begin{array}{l}\text { Allogeneic } \\
\text { tumor vaccine }\end{array}$ & $\begin{array}{l}\text { Tumor lysate with } \\
\text { adjuvant (SC) }\end{array}$ & Hemangiosarcoma & 28 & OST, tumor progression & Antibody response & $\begin{array}{l}\text { Increase survival vs. } \\
\text { historical control }\end{array}$ & $(54)$ \\
\hline $\begin{array}{l}\text { Bacterial } \\
\text { immunotherapy }\end{array}$ & $\begin{array}{l}\text { Attenuated } \\
\text { Salmonella (IV) }\end{array}$ & $\begin{array}{l}\text { Multiple } \\
\text { tumor types }\end{array}$ & 41 & Tumor regression & $\begin{array}{l}\text { Bacterial } \\
\text { localization }\end{array}$ & $\begin{array}{l}15 \% \text { overall response } \\
\text { rate; dose dependent } \\
\text { toxicity }\end{array}$ & (55) \\
\hline $\begin{array}{l}\text { Local } \\
\text { superantigen } \\
\text { immunotherapy }\end{array}$ & $\begin{array}{l}\text { Plasmid DNA, } \\
\text { intratumoral }\end{array}$ & Melanoma & 26 & Tumor regression, OST & Immune infiltrates & $\begin{array}{l}\text { Increased survival vs. } \\
\text { historical control; CTL } \\
\text { activity }\end{array}$ & $(56)$ \\
\hline Liposomal MTP & IV, repeat infusions & Osteosarcoma & 98 & DFI and OST & $\begin{array}{l}\text { Macrophage } \\
\text { activation }\end{array}$ & $\begin{array}{l}\text { DFI and OST } \\
\text { significantly increased }\end{array}$ & $(57)$ \\
\hline
\end{tabular}




\section{Cancer Vaccines}

A key question related to the new generation of cancer vaccines currently under development, which is difficult to fully address in rodent models, is whether they can effectively prevent metastatic disease, or control metastases once they develop. As noted above, dogs develop several highly metastatic cancers closely related to human cancers, including in particular osteosarcoma and melanoma $(6,20,57)$. These cancers in dogs therefore offer an opportunity to test new cancer vaccine approaches in immunologically realistic settings. As an example, studies are currently underway in dogs with osteosarcoma to determine whether a newly conditionally approved canine osteosarcoma Listeria-vectored vaccine targeting HER2/neu can effectively prevent tumor metastases, and control the growth of macroscopic metastases (46). This novel vaccine approach has demonstrated remarkable early evidence of activity as adjuvant therapy for dogs with osteosarcoma at high risk for tumor metastases. Another example is a plasmid-DNA based tumor vaccine targeting the TERT antigen, which has been evaluated in dogs with lymphoma in combination with CHOP chemotherapy $(47,58)$. The vaccine has also demonstrated impressive antitumor activity, as reflected in prolonged disease-free intervals compared to relevant chemotherapy only control animals. A number of other cancer vaccine targets are currently being evaluated in canine immunotherapy studies, including the GD3 antigen in canine melanoma studies (59).

\section{Adoptive Cellular Therapy}

Adoptive cell therapy (ACT) with CAR T cells has transformed the treatment of certain leukemias and several other hematopoietic cancers in humans. However, progress in using CAR T cells to treat solid tumors in humans has been more fraught with difficulty, including serious and occasionally fatal toxicities, as well as less overall anti-tumor activity. The adverse events associated with CAR T cell treatment of solid tumors were unfortunately not predicted by rodent cancer models. Given the strong similarities between canine and human immune responses, dogs with solid tumors offer a unique opportunity to evaluate the safety and potential efficacy of new ACTs such as CAR $\mathrm{T}$ cell therapy before initiating human clinical trials. Indeed, ACT with CAR T cells has been evaluated in small scale studies in dogs, including CAR T cell studies with a CD20 targeted CAR T cells in dogs with B cell lymphoma (49). Other opportunities for use of the dog tumor model include evaluation of ACT with CAR T or CAR NK cells specific for other widely expressed tumor antigens in dogs, including HER2/neu, EGFR, and GD2 (60). For example, ACT using activated canine NK cells has shown early promise in conjunction with radiation therapy in a dog osteosarcoma model (50).

\section{Tumor Microenvironment Modification}

Increasingly studies point to the essential role of the tumor microenvironment (TME) in regulating overall anti-tumor immune responses. Thus, a new wave of therapeutics that target the TME are under development and evaluation in clinical trials. Our studies have identified a wide spectrum of immune responses in tumor tissues of dogs, ranging from highly inflammatory tumors (e.g., melanoma) to tumors that are immunologically "cold" (e.g., soft tissue sarcoma, mast cell tumors, osteosarcoma) (Regan D; Flint Animal Cancer Center, unpublished data). Each of these tumor models in dogs therefore offers the opportunity for evaluation of agents that target the TME, particularly for those designed to remove immune suppressive cells to help activate immunologically "cold" tumors. For example, depleting target tumor-associated macrophages by administration of agents such as liposomal clodronate that deplete tumor macrophages outright has been evaluated in dogs $(51,61)$. We also found that modifying the TME by direct tumor transfection with a potent T cell activating molecule such as a bacterial superantigen could stimulate $\mathrm{T}$ cell infiltration and activation and significant tumor regression in dogs with melanoma [Figure 1; (56)].

A second strategy to eliminate the immune suppressive tumor macrophage population is to prevent their recruitment to tumor tissues by administering agents that block signaling by the
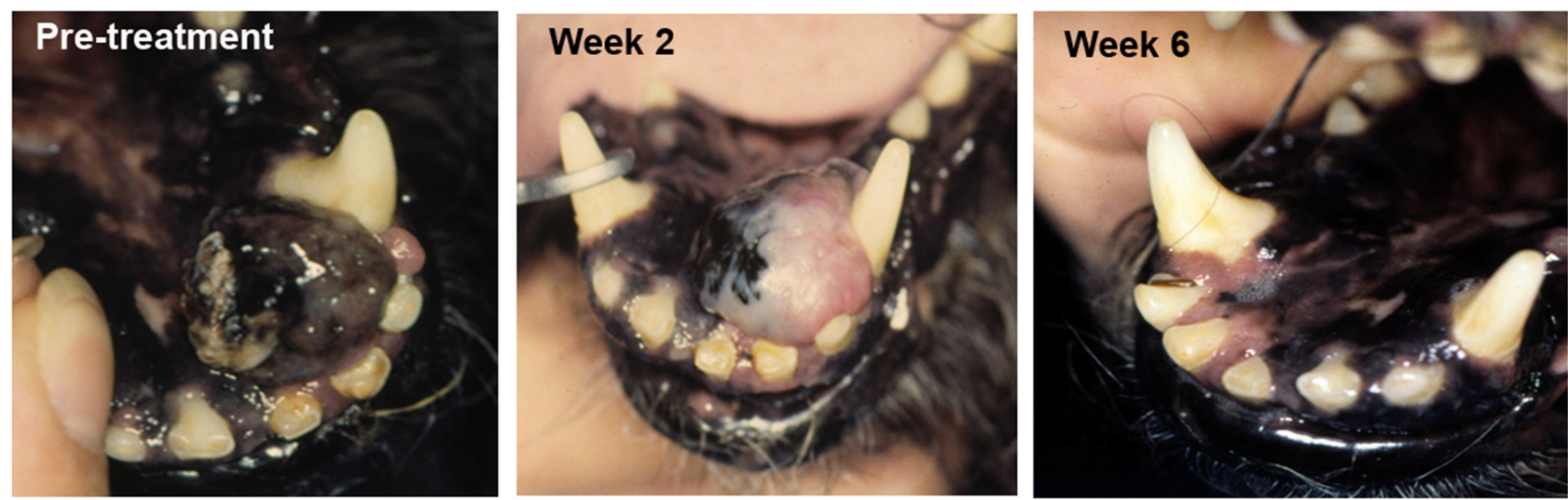

FIGURE 1 | Tumor response to TME modification with a T cell activator. A dog with oral malignant melanoma (left panel) was treated with a series of every 2 week intratumoral injections of plasmid DNA encoding a bacterial superantigen gene (SEB), along with an IL-2 encoding plasmid. Tumor depigmentation was evident after the first injection (middle image) and complete tumor regression was noted after the second intratumoral injection (right panel). 
chemokine receptor CCR2. Given that there are no currently approved (or affordable) pure CCR2 antagonists available for evaluation in dogs, our group has identified several drugs, most notably angiotensin receptor antagonists (ARBs), that can be repurposed as monocyte migration inhibitors. For example, we reported recently that the ARB losartan exerts potent antitumor activity by blocking signaling via the CCR 2 chemokine receptor, thereby inhibiting the recruitment of inflammatory monocytes into tumor tissues, leading to overall tumor macrophage depletion (62). A recently completed clinical trial in dogs with metastatic osteosarcoma treated with high-dose losartan immunotherapy demonstrated significant antitumor activity and systemic suppression of monocyte migration (Regan et al., in review).

As another strategy to modify the TME, it was recently reported that blockade of CCR4 signaling with humanized antibodies could significantly deplete Tregs in a canine model of invasive bladder cancer (52). In that study, treatment with an anti-CCR4 antibody depleted Tregs in bladder tumor tissues in dogs, and was associated with sustained tumor regression, and prolonged survival.

Other groups have investigated indoleamine deoxygenase inhibitors, which target an immune suppressive metabolic pathway in the TME $(53,63)$. The hypoxic TME in brain cancer can also be modified by administering agents that increase tumor oxygenation in dogs, in conjunction with radiation (64). Thus, the dog cancer model offers multiple opportunities to evaluate TME modulating drugs, particularly because many of these studies have relatively simple PD endpoints and may be of relatively short duration if the primary study endpoints are changes in the TME rather than tumor responses per se.

\section{Checkpoint Molecule Targeted Immunotherapies}

Checkpoint targeted therapeutics are far advanced in development and approval for treatment of multiple cancers in humans. As new checkpoint molecule targeted drugs become available in dogs, opportunities exist where the dog model may provide important new information, particularly with respect rational combination therapies of immune targeted drugs given with checkpoint inhibitors. A fully canine PD-1 antibody is currently nearing phase I trial completion in dogs with a variety of different cancers and a product launch is possible in 2020 (40). Other canine checkpoint targeted antibodies are also in the pipeline, including PD-L1 and OX40 antibodies. In addition, several small molecule inhibitors of checkpoint molecules are being investigated in clinical tumor vaccine trials in dogs with brain cancer (64-66).

Thus, the anticipated availability of new checkpoint immunotherapy reagents will make it possible to conduct creative trials in dogs. For example, a number of questions could be addressed, including: Are checkpoint molecule therapeutics effective when administered in an adjuvant setting in dogs with highly metastatic disease such as osteosarcoma or hemangiosarcoma? Or can checkpoint inhibitors be effectively combined with cytotoxic drugs such as CHOP for treatment of
TABLE 2 | Immunological reagents for cell identification and functional assessment in dogs with cancer.

\begin{tabular}{|c|c|c|}
\hline Molecule & Cellular expression & Usage \\
\hline CD3 & T cells & $\mathrm{FC}, \mathrm{IHC}$ \\
\hline CD5 & T cells & $\mathrm{FC}$ \\
\hline CD4 & Th subset, neutrophils & $\mathrm{FC}, \mathrm{IHC}$ \\
\hline CD8 & Tc subset & $\mathrm{FC}, \mathrm{IHC}$ \\
\hline CD9 & Myeloid cells, T cells & FC \\
\hline CD11a & Leukocytes, memory T cells & FC \\
\hline CD11b & Myeloid cells & $\mathrm{FC}, \mathrm{IHC}$ \\
\hline CD11c & DC, some macrophages & $\mathrm{FC}, \mathrm{IHC}$ \\
\hline CD14 & Monocytes, some neutrophils & FC \\
\hline CD18 & Myeloid cells, MH & $\mathrm{FC}, \mathrm{IHC}$ \\
\hline CD19, CD20, CD21 & B cells, lymphoma & $\mathrm{FC}$ \\
\hline CD25 & Activated T cells, Tregs & FC \\
\hline CD31 & Endothelial cells & $\mathrm{IHC}$ \\
\hline CD34 & Hematopoietic stem cells & FC \\
\hline CD40 & APC & FC \\
\hline CD45 & All hematopoietic cells & FC \\
\hline CD61 & Platelets & FC \\
\hline CD79a & Pre-B cell & $\mathrm{IHC}$ \\
\hline CD86 & APC & $\mathrm{FC}$ \\
\hline $\mathrm{MHCll}$ & T cells, APC & $\mathrm{FC}, \mathrm{IHC}$ \\
\hline FoxP3 & Regulatory T cells & $\mathrm{FC}, \mathrm{IHC}$ \\
\hline Granzyme B & T cells & $\mathrm{FC}, \mathrm{IHC}$ \\
\hline TNF-a & T cells, APC & $\mathrm{FC}, \mathrm{IHC}$ \\
\hline IFN-g & T cells, NK cells & $\mathrm{FC}, \mathrm{IHC}$ \\
\hline EOMES & T cell (exhausted; memory) & FC \\
\hline Tim-3 & T cell (exhausted) & FC \\
\hline PD-1 & T cell (exhausted); also recently activated & FC \\
\hline PD-L1 & Monocyte, macrophage, DC & $\mathrm{FC}, \mathrm{IHC}$ \\
\hline Ki67 & Proliferating cells & $\mathrm{FC}, \mathrm{HC}$ \\
\hline
\end{tabular}

lymphoma? Or does co-administration of a checkpoint inhibitor with a tumor vaccine such as the Her2/neu vaccine improve vaccine efficacy in the setting of advanced, bulky tumors? As these examples suggest, a number of important questions related to adjuvant therapy and checkpoint therapy combinations can be addressed in targeted populations of dogs with relevant cancers.

\section{Other Immunotherapy Approaches}

Additional promising cancer immunotherapy strategies are also under evaluation in the dog cancer model. These include the use of viral vectored cytokine delivery approaches (brain cancer), systemic administration of IL-12 nanoparticles (soft tissue sarcoma), bacterial delivered therapeutics (e.g., engineered hypoxia targeting Salmonella in soft tissue sarcoma), regulatory T cell depletion with metronomically delivered chemotherapeutics (e.g., toceranib), adoptive transfer of non-specifically activated $\mathrm{T}$ cells and IL-15 activated NK cells (osteosarcoma), along with a variety of different cancer vaccines $(50,55,67)$. Thus, the canine oncology field has widely embraced the potential for immunotherapy, and it is likely this trend will 
TABLE 3 | Cytokine reagents for dogs.

\begin{tabular}{lll}
\hline Cytokine & Expression & Format \\
\hline IL-1b & Monocyte, macrophage & ELISA, multiplex \\
IL-2 & T cells, NK cells, B cells & ELISA, multiplex \\
IL-4 & Th2 T cells & ELISA \\
IL-6 & Macrophage, T cells & ELISA, multiplex \\
IL-7 & Multiple & multiplex \\
IL-8 & Multiple & ELISA, multiplex \\
IL-10 & APC, T cells & ELISA \\
IL-12 & APC & ELISA \\
IL-15 & Monocytes, others & multiplex \\
IL-18 & APC & multiplex \\
MCP-1 & Multiple & ELISA, multiplex \\
TNF-a & APC, T cells & ELISA, multiplex \\
GM-CSF & Multiple & multiplex \\
IFN-g & T cell, NK cell & ELISA, multiplex \\
\hline
\end{tabular}

continue in the future. Data from rigorously conducted trials of immunotherapy in dogs, paired with immune biomarker correlates (9) will help increase the impact of these studies on the human immuno-oncology.

\section{Challenges for Immunotherapy Studies in Dogs}

While there is great promise for studies in dogs with cancer to contribute to the advancement of immunotherapy for both dogs and humans, there are still challenges inherent to the dog immunotherapy model that must be addressed. Among these challenges is a perceived lack of necessary immunological reagents. Though this issue is often cited as a major impediment to immunotherapy studies in dogs, the reality is different (see Tables 2 and 3). For example, there are currently more than sufficient reagents available for evaluating immune responses to cancer, including $\mathrm{T}$ and $\mathrm{B}$ cell responses (activation, exhaustion, proliferation), monocyte and macrophage responses (numbers, functional phenotype), regulatory T cells (numbers), neutrophils (numbers, function), and NK cells (numbers, function) (Table 2). In addition, there are now a large variety of cytokine reagents for dog studies, including cytokine ELISAs, cytokine multiplexing kits, and antibodies for intracellular cytokine staining and analysis by flow cytometry (Table 3). It is also possible to assess immune responses in archived tissues and cells, using qRT-PCR and Nanostring technology, as well as next generation sequencing technologies (e.g., RNA sequencing).

\section{REFERENCES}

1. Wege AK. Humanized mouse models for the preclinical assessment of cancer immunotherapy. BioDrugs. (2018) 32:24566. doi: 10.1007/s40259-018-0275-4

2. Garden OA, Volk SW, Mason NJ, Perry JA. Companion animals in comparative oncology: one Medicine in action. Vet J. (2018) 240:613. doi: $10.1016 / j . t v j l .2018 .08 .008$
Another important challenge of the dog model is related to the costs associated with upscaling drugs and immunological reagents for conducting pre-clinical studies in dogs, given their larger body size vs. mice. Moreover, there are substantial costs in terms of personnel (veterinarians, technicians, laboratory personnel) required to support such studies. However, all of these challenges are surmountable, given sufficient support from funding agencies, including more recently the NIH. The setting of realistic expectations at the outset of studies also helps minimize the impacts of these challenges.

\section{Summary and Conclusions}

The era of effective cancer immunotherapy represents a major change in how cancer is treated, and the dog cancer model undoubtedly has an opportunity to play an important role in advancing this field. The value of the dog cancer model for immunotherapy has been demonstrated previously, with the best example being the essential role played by dogs with osteosarcoma development of the non-specific immunotherapeutic L-MTP (liposomal muramyl tripeptide) as an approved immunotherapy for pediatric osteosarcoma $(57,68)$. The key to leveraging the dog model to advance such studies will be to identify questions that cannot be answered currently in rodent models, and to move nimbly to propose studies that can be informative within a short time frame (months), since the immunotherapy field moves so rapidly. Procuring adequate drug supplies and reagents for large animal studies is also essential. Finally, broad collaborations will always advance the field more effectively than single institution studies, particularly in situations where essential reagents must be shared or where access to patients with certain tumor types is limited. The best possible outcomes will be studies where the results can be translated promptly to benefit both dogs and humans, with their shared tumor types and strong bonds.

\section{AUTHOR CONTRIBUTIONS}

The author confirms being the sole contributor of this work and has approved it for publication.

\section{FUNDING}

The author wishes to acknowledge support from grants U01 CA224182-01 (SD) and an administrative supplement to CA143971(D. Theodorescu, University of Colorado Denver) from the National Cancer Institute of the National Institutes of Health, the Canine Health Foundation, and the Charles Shipley Foundation.

3. Park JS, Withers SS, Modiano JF, Kent MS, Chen M, Luna JI, et al. Canine cancer immunotherapy studies: linking mouse and human. J Immunother Cancer. (2016) 4:97. doi: 10.1186/s40425-016-0200-7

4. Withrow SJ, Khanna C. Bridging the gap between experimental animals and humans in osteosarcoma. Cancer Treat Res. (2009) 152:439-46. doi: 10.1007/978-1-4419-0284-9_24

5. Buque A, Galluzzi L. Modeling tumor immunology and immunotherapy in mice. Trends Cancer. (2018) 4:599-601. doi: 10.1016/j.trecan.2018.07.003 
6. Khanna C, Lindblad-Toh K, Vail D, London C, Bergman P, Barber L, et al. The $\operatorname{dog}$ as a cancer model. Nat Biotechnol. (2006) 24:10656. doi: 10.1038/nbt0906-1065b

7. Khanna C, Gordon I. Catching cancer by the tail: new perspectives on the use of kinase inhibitors. Clin Cancer Res. (2009) 15:36457. doi: 10.1158/1078-0432.CCR-09-0132

8. Khanna C, London C, Vail D, Mazcko C, Hirschfeld S. Guiding the optimal translation of new cancer treatments from canine to human cancer patients. Clin Cancer Res. (2009) 15:5671-7. doi: 10.1158/1078-0432.CCR-09-0719

9. LeBlanc AK, Breen M, Choyke P, Dewhirst M, Fan TM, Gustafson DL, et al. Perspectives from man's best friend: National Academy of Medicine's Workshop on Comparative Oncology. Sci Transl Med. (2016) 8:324ps5. doi: 10.1126/scitranslmed.aaf0746

10. Paoloni M, Khanna C. Translation of new cancer treatments from pet dogs to humans. Nat Rev Cancer. (2008) 8:147-56. doi: 10.1038/nrc2273

11. Paoloni MC, Khanna C. Comparative oncology today. Vet Clin North Am Small Anim Pract. (2007) 37:1023-32. doi: 10.1016/j.cvsm.2007.08.003

12. Paoloni MC, Tandle A, Mazcko C, Hanna E, Kachala S, Leblanc A, et al. Launching a novel preclinical infrastructure: comparative oncology trials consortium directed therapeutic targeting of TNFalpha to cancer vasculature. PLoS ONE. (2009) 4:e4972. doi: 10.1371/journal.pone.0004972

13. Vail DM, MacEwen EG. Spontaneously occurring tumors of companion animals as models for human cancer. Cancer Invest. (2000) 18:78192. doi: 10.3109/07357900009012210

14. Addissie S, Klingemann H. Cellular immunotherapy of canine cancer. Vet Sci. (2018) 5:E100. doi: 10.3390/vetsci5040100

15. Almela RM, Anson A. A Review of immunotherapeutic strategies in canine malignant melanoma. Vet Sci. (2019) 6:15. doi: 10.3390/vetsci6010015

16. Bergman PJ. Immunotherapy in veterinary oncology. Vet Clin North Am Small Anim Pract. (2014) 44:925-39. doi: 10.1016/j.cvsm.2014.05.002

17. Klingemann H. Immunotherapy for dogs: running behind humans. Front Immunol. (2018) 9:133. doi: 10.3389/fimmu.2018.00133

18. O'Connor CM, Wilson-Robles H. Developing T cell cancer immunotherapy in the dog with lymphoma. ILAR J. (2014) 55:169-81. doi: 10.1093/ilar/ilu020

19. Regan D, Dow S. Manipulation of innate immunity for cancer therapy in dogs. Vet Sci. (2015) 2:423-39. doi: 10.3390/vetsci2040423

20. Regan D, Guth A, Coy J, Dow S. Cancer immunotherapy in veterinary medicine: current options and new developments. Vet J. (2016) 207:208. doi: 10.1016/j.tvjl.2015.10.008

21. Elvers I, Turner-Maier J, Swofford R, Koltookian M, Johnson J, Stewart C, et al. Exome sequencing of lymphomas from three dog breeds reveals somatic mutation patterns reflecting genetic background. Genome Res. (2015) 25:1634-45. doi: $10.1101 /$ gr.194449.115

22. Chen HW, Small GW, Motsinger-Reif A, Suter SE, Richards KL. VH144 gene usage defines a subset of canine B-cell lymphomas associated with better patient survival. Vet Immunol Immunopathol. (2014) 157:12530. doi: 10.1016/j.vetimm.2013.10.020

23. Ostrander EA, Dreger DL, Evans JM. Canine cancer genomics: lessons for canine and human health. Annu Rev Anim Biosci. (2019) 7:44972. doi: 10.1146/annurev-animal-030117-014523

24. Tarone L, Barutello G, Iussich S, Giacobino D, Quaglino E, Buracco P, et al. Naturally occurring cancers in pet dogs as pre-clinical models for cancer immunotherapy. Cancer Immunol Immunother. (2019) 68:183953. doi: 10.1007/s00262-019-02360-6

25. Dhawan D, Paoloni M, Shukradas S, Choudhury DR, Craig BA, Ramos-Vara JA, et al. Comparative gene expression analyses identify luminal and basal subtypes of canine invasive urothelial carcinoma that mimic patterns in human invasive bladder cancer. PLoS ONE. (2015) 10:e0136688. doi: 10.1371/journal.pone. 0136688

26. Davis BW, Ostrander EA. Domestic dogs and cancer research: a breed-based genomics approach. ILAR J. (2014) 55:59-68. doi: 10.1093/ilar/ilu017

27. Abdelmegeed SM, Mohammed S. Canine mammary tumors as a model for human disease. Oncol Lett. (2018) 15:8195-205. doi: 10.3892/ol.2018.8411

28. Foltz JA, Somanchi SS, Yang Y, Aquino-Lopez A, Bishop EE, Lee DA. NCR1 expression identifies canine natural killer cell subsets with phenotypic similarity to human natural killer cells. Front Immunol. (2016) 7:521. doi: 10.3389/fimmu.2016.00521
29. Graves SS, Gyurkocza B, Stone DM, Parker MH, Abrams K, Jochum C, et al. Development and characterization of a canine-specific anti-CD94 (KLRD-1) monoclonal antibody. Vet Immunol Immunopathol. (2019) 211:108. doi: 10.1016/j.vetimm.2019.03.005

30. Ortiz AL, Carvalho S, Leo C, Riondato F, Archer J, Cian F. Gamma delta Tcell large granular lymphocyte lymphoma in a dog. Vet Clin Pathol. (2015) 44:442-7. doi: $10.1111 / \mathrm{vcp} .12265$

31. Biller BJ, Elmslie RE, Burnett RC, Avery AC, Dow SW. Use of FoxP3 expression to identify regulatory $\mathrm{T}$ cells in healthy dogs and dogs with cancer. Vet Immunol Immunopathol. (2007) 116:69-78. doi: 10.1016/j.vetimm.2006.12.002

32. Biller BJ, Guth A, Burton JH, Dow SW. Decreased ratio of CD8+ $\mathrm{T}$ cells to regulatory $\mathrm{T}$ cells associated with decreased survival in dogs with osteosarcoma. J Vet Intern Med. (2010) 24:1118-23. doi: 10.1111/j.1939-1676.2010.0557.x

33. O'Neill K, Guth A, Biller B, Elmslie R, Dow S. Changes in regulatory T cells in dogs with cancer and associations with tumor type. J Vet Intern Med. (2009) 23:875-81. doi: 10.1111/j.1939-1676.2009.0333.x

34. Bergeron LM, McCandless EE, Dunham S, Dunkle B, Zhu Y, Shelly J, et al. Comparative functional characterization of canine IgG subclasses. Vet Immunol Immunopathol. (2014) 157:31-41. doi: 10.1016/j.vetimm.2013.10.018

35. Lee SH, Shin DJ, Kim Y, Kim CJ, Lee JJ, Yoon MS, et al. Comparison of phenotypic and functional characteristics between canine NonB, Non-T natural killer lymphocytes and $\mathrm{CD} 3(+) \mathrm{CD} 5(\operatorname{dim}) \mathrm{CD} 21(-)$ cytotoxic large granular lymphocytes. Front Immunol. (2018) 9:841. doi: 10.3389/fimmu.2018.00841

36. Wheat WH, Chow L, Kurihara JN, Regan DP, Coy JW, Webb TL, et al. Suppression of canine dendritic cell activation/maturation and inflammatory cytokine release by mesenchymal stem cells occurs through multiple distinct biochemical pathways. Stem Cells Dev. (2017) 26:24962. doi: $10.1089 / \mathrm{scd} .2016 .0199$

37. Hartley G, Regan D, Guth A, Dow S. Regulation of PD-L1 expression on murine tumor-associated monocytes and macrophages by locally produced TNF-alpha. Cancer Immunol Immunother. (2017) 66:523-35. doi: 10.1007/s00262-017-1955-5

38. Hartley G, Faulhaber E, Caldwell A, Coy J, Kurihara J, Guth A, et al. Immune regulation of canine tumour and macrophage PD-L1 expression. Vet Comp Oncol. (2017) 15:534-49. doi: 10.1111/vco.12197

39. Hartley G, Elmslie R, Dow S, Guth A. Checkpoint molecule expression by $\mathrm{B}$ and $\mathrm{T}$ cell lymphomas in dogs. Vet Comp Oncol. (2018) 16:35260. doi: $10.1111 /$ vco. 12386

40. Coy J, Caldwell A, Chow L, Guth A, Dow S. PD-1 expression by canine $\mathrm{T}$ cells and functional effects of PD-1 blockade. Vet Comp Oncol. (2017) 15:1487-502. doi: 10.1111/vco.12294

41. Regan DP, Escaffi A, Coy J, Kurihara J, Dow SW. Role of monocyte recruitment in hemangiosarcoma metastasis in dogs. Vet Comp Oncol. (2017) 15:130922. doi: $10.1111 / \mathrm{vco} .12272$

42. Friedrichs KR, Young KM. Histiocytic sarcoma of macrophage origin in a cat: case report with a literature review of feline histiocytic malignancies and comparison with canine hemophagocytic histiocytic sarcoma. Vet Clin Pathol. (2008) 37:121-8. doi: 10.1111/j.1939-165X.2008.00005.x

43. Coomer AR, Liptak JM. Canine histiocytic diseases. Compend Contin Educ Vet. (2008) 30:202-4, 208-16; quiz 216-17.

44. Moore PF. A review of histiocytic diseases of dogs and cats. Vet Pathol. (2014) 51:167-84. doi: 10.1177/0300985813510413

45. Killick DR, Stell AJ, Catchpole B. Immunotherapy for canine cancer-is it time to go back to the future? J Small Anim Pract. (2015) 56:22941. doi: $10.1111 /$ jsap. 12336

46. Mason NJ, Gnanandarajah JS, Engiles JB, Gray F, Laughlin D, GaurnierHausser A, et al. Immunotherapy with a HER2-targeting listeria induces HER2-specific immunity and demonstrates potential therapeutic effects in a phase I trial in canine osteosarcoma. Clin Cancer Res. (2016) 22:438090. doi: 10.1158/1078-0432.CCR-16-0088

47. Peruzzi D, Gavazza A, Mesiti G, Lubas G, Scarselli E, Conforti A, et al. A vaccine targeting telomerase enhances survival of dogs affected by B-cell lymphoma. Mol Ther. (2010) 18:1559-67. doi: 10.1038/mt.2010.104 
48. Andersen BM, Pluhar GE, Seiler CE, Goulart MR, SantaCruz KS, Schutten MM, et al. Vaccination for invasive canine meningioma induces in situ production of antibodies capable of antibodydependent cell-mediated cytotoxicity. Cancer Res. (2013) 73:2987-97. doi: 10.1158/0008-5472.CAN-12-3366

49. Panjwani MK, Smith JB, Schutsky K, Gnanandarajah J, O’Connor CM, Powell DJ Jr., et al. Feasibility and safety of RNA-transfected CD20-specific chimeric antigen receptor $\mathrm{T}$ cells in dogs with spontaneous $\mathrm{B}$ cell lymphoma. Mol Ther. (2016) 24:1602-14. doi: 10.1038/mt.2016.146

50. Canter RJ, Grossenbacher SK, Foltz JA, Sturgill IR, Park JS, Luna JI, et al. Radiotherapy enhances natural killer cell cytotoxicity and localization in preclinical canine sarcomas and first-in-dog clinical trial. J Immunother Cancer. (2017) 5:98. doi: 10.1186/s40425-017-0305-7

51. Guth AM, Hafeman SD, Elmslie RE, Dow SW. Liposomal clodronate treatment for tumour macrophage depletion in dogs with soft-tissue sarcoma. Vet Comp Oncol. (2013) 11:296-305. doi: 10.1111/j.1476-5829.2012. 00319.x

52. Maeda S, Murakami K, Inoue A, Yonezawa T, Matsuki N. CCR4 blockade depletes regulatory $\mathrm{T}$ cells and prolongs survival in a canine model of bladder cancer. Cancer Immunol Res. (2019) 7:1175-87. doi: 10.1158/2326-6066.CIR-18-0751

53. Monjazeb AM, Kent MS, Grossenbacher SK, Mall C, Zamora AE, Mirsoian A, et al. Blocking indolamine-2,3-dioxygenase rebound immune suppression boosts antitumor effects of radio-immunotherapy in murine models and spontaneous canine malignancies. Clin Cancer Res. (2016) 22:432840. doi: 10.1158/1078-0432.CCR-15-3026

54. U'Ren LW, Biller BJ, Elmslie RE, Thamm DH, Dow SW. Evaluation of a novel tumor vaccine in dogs with hemangiosarcoma. J Vet Intern Med. (2007) 21:113-20. doi: 10.1892/0891-6640(2007)21[113:eoantv]2.0.co;2

55. Thamm DH, Kurzman ID, King I, Li Z, Sznol M, Dubielzig RR, et al. Systemic administration of an attenuated, tumor-targeting Salmonella typhimurium to dogs with spontaneous neoplasia: phase I evaluation. Clin Cancer Res. (2005) 11:4827-34. doi: 10.1158/1078-0432.CCR-04-2510

56. Dow SW, Elmslie RE, Willson AP, Roche L, Gorman C, Potter TA. In vivo tumor transfection with superantigen plus cytokine genes induces tumor regression and prolongs survival in dogs with malignant melanoma. J Clin Invest. (1998) 101:2406-14. doi: 10.1172/JCI510

57. MacEwen EG, Kurzman ID, Vail DM, Dubielzig RR, Everlith K, Madewell $\mathrm{BR}$, et al. Adjuvant therapy for melanoma in dogs: results of randomized clinical trials using surgery, liposome-encapsulated muramyl tripeptide, and granulocyte macrophage colony-stimulating factor. Clin Cancer Res. (1999) 5:4249-58.

58. Thalmensi J, Pliquet E, Liard C, Chamel G, Kreuz C, Bestetti T, et al. A DNA telomerase vaccine for canine cancer immunotherapy. Oncotarget. (2019) 10:3361-72. doi: 10.18632/oncotarget. 26927

59. Milner RJ, Salute M, Crawford C, Abbot JR, Farese J. The immune response to disialoganglioside GD3 vaccination in normal dogs: a melanoma surface antigen vaccine. Vet Immunol Immunopathol. (2006) 114:27384. doi: 10.1016/j.vetimm.2006.08.012
60. Yin Y, Boesteanu AC, Binder ZA, Xu C, Reid RA, Rodriguez JL, et al. Checkpoint blockade reverses anergy in IL-13R $\alpha 2$ humanized scFv-based CAR T cells to treat murine and canine gliomas. Mol Ther Oncolytics. (2018) 11:20-38. doi: 10.1016/j.omto.2018.08.002

61. Guth AM, Hafeman SD, Dow SW. Depletion of phagocytic myeloid cells triggers spontaneous T cell- and NK cell-dependent antitumor activity. Oncoimmunology. (2012) 1:1248-57. doi: 10.4161/onci.21317

62. Regan DP, Coy JW, Chahal KK, Chow L, Kurihara JN, Guth $\mathrm{AM}$, et al. The angiotensin receptor blocker losartan suppresses growth of pulmonary metastases via AT1R-independent inhibition of CCR2 signaling and monocyte recruitment. J Immunol. (2019) 202:3087-102. doi: 10.4049/jimmunol.1800619

63. Porcellato I, Brachelente C, De Paolis L, Menchetti L, Silvestri S, Sforna M, Vichi G, et al. FoxP3 and IDO in canine melanocytic tumors. Vet Pathol. (2019) 56:189-99. doi: 10.1177/0300985818808530

64. Rossmeisl JH. New treatment modalities for brain tumors in dogs and cats. Vet Clin North Am Small Anim Pract. (2014) 44:101338. doi: 10.1016/j.cvsm.2014.07.003

65. Olin MR, Pluhar GE, Andersen BM, Shaver R, Waldron NN, Moertel CL. Victory and defeat in the induction of a therapeutic response through vaccine therapy for human and canine brain tumors: a review of the state of the art. Crit Rev Immunol. (2014) 34:399-432. doi: 10.1615/CritRevImmunol.2014011577

66. Hubbard ME, Arnold S, Bin Zahid A, McPheeters M, Gerard O'Sullivan M, Tabaran AF, et al. Naturally occurring canine glioma as a model for novel therapeutics. Cancer Invest. (2018) 36:415-23. doi: 10.1080/07357907.2018.1514622

67. Paoloni M, Mazcko C, Selting K, Lana S, Barber L, Phillips J, et al. Defining the pharmacodynamic profile and therapeutic index of NHS-IL12 immunocytokine in dogs with malignant melanoma. PLoS ONE. (2015) 10:e0129954. doi: 10.1371/journal.pone.0129954

68. Kurzman ID, MacEwen EG, Rosenthal RC, Fox LE, Keller ET, Helfand SC, et al. Adjuvant therapy for osteosarcoma in dogs: results of randomized clinical trials using combined liposome-encapsulated muramyl tripeptide and cisplatin. Clin Cancer Res. (1995) 1:1595-601.

Disclaimer: The content of the publication is the responsibility of the author and does not necessarily reflect the official views of the National Institutes of Health, the Canine Health Foundation, nor the Shipley Foundation.

Conflict of Interest: The author declares that the research was conducted in the absence of any commercial or financial relationships that could be construed as a potential conflict of interest.

Copyright (c) 2020 Dow. This is an open-access article distributed under the terms of the Creative Commons Attribution License (CC BY). The use, distribution or reproduction in other forums is permitted, provided the original author(s) and the copyright owner(s) are credited and that the original publication in this journal is cited, in accordance with accepted academic practice. No use, distribution or reproduction is permitted which does not comply with these terms. 